\title{
A prospective, randomized, double-blind, and multicenter trial of prophylactic effects of ramosetron on postoperative nausea and vomiting (PONV) after craniotomy: comparison with ondansetron
}

Jung-Hee Ryu ${ }^{1,3}$, Ji-Eun Lee ${ }^{2}$, Young-Jin Lim²,3, Deok-Man Hong ${ }^{2,3}$, Hee-Pyoung Park ${ }^{2,3}$, Jong-In Han ${ }^{4}$, Hee-Jung Baik4, Hyun-Zu Kim ${ }^{5}$, Kyeong-Tae Min ${ }^{5}$ and Sang-Hwan Do ${ }^{1,3^{*}}$

\begin{abstract}
Background: Craniotomy patients have a high incidence of postoperative nausea and vomiting (PONV). This prospective, randomized, double-blind, multi-center study was performed to evaluate the efficacy of prophylactic ramosetron in preventing PONV compared with ondansetron after elective craniotomy in adult patients.

Methods: A total of 160 American Society of Anesthesiologists physical status I-II patients aged 19-65 years who were scheduled to undergo elective craniotomy for various intracranial lesions were enrolled in this study. All patients received total intravenous anesthesia (TIVA) with propofol and remifentanil. Patients were randomly allocated into three groups to receive ondansetron ( $4 \mathrm{mg}$; group $\mathrm{A}, n=55$ ), ondansetron ( $8 \mathrm{mg}$; group $\mathrm{B}, n=54$ ), or ramosetron ( $0.3 \mathrm{mg}$; group $C, n=51$ ) intravenously at the time of dural closure. The incidence of PONV, the need for rescue antiemetics, pain score, patient-controlled analgesia (PCA) consumption, and adverse events were recorded $48 \mathrm{~h}$ postoperatively.
\end{abstract}

Results: Among the initial 160 patients, 127 completed the study and were included in the final analysis. The incidences of PONV were lower (nausea, $14 \%$ vs. $59 \%$ and $41 \%$, respectively; $P<0.001$; vomiting, $P=0.048$ ) and the incidence of complete response was higher ( $83 \%$ vs. $37 \%$ and $59 \%$, respectively; $P<0.001)$ in group $C$ than in groups $A$ and $B$ at 48 h postoperatively. There were no significant differences in the incidence of PONV or need for rescue antiemetics $0-2 \mathrm{~h}$ postoperatively, but significant differences were observed in the incidence of PONV and complete response among the three groups $2-48 \mathrm{~h}$ postoperatively. No statistically significant intergroup differences were observed in postoperative pain, PCA consumption, or adverse events.

Conclusion: Intravenous administration of ramosetron at $0.3 \mathrm{mg}$ reduced the incidence of PONV and rescue antiemetic requirement in craniotomy patients. Ramosetron at $0.3 \mathrm{mg}$ was more effective than ondansetron at 4 or $8 \mathrm{mg}$ for preventing PONV in adult craniotomy patients.

Trial registration: Clinical Research Information Service (CRiS) Identifier: KCT0000320. Registered 9 January 2012. Keywords: Craniotomy, Ondansetron, Postoperative nausea and vomiting, Ramosetron

\footnotetext{
* Correspondence: shdo@snu.ac.kr

${ }^{1}$ Department of Anesthesiology and Pain Medicine, Seoul National University

Bundang Hospital, 166 Gumi-ro, Bundang-gu, Seongnam-si, Gyeonggi-do

463-707, South Korea

${ }^{3}$ Department of Anesthesiology and Pain Medicine, College of Medicine,

Seoul National University, Seoul, South Korea

Full list of author information is available at the end of the article
} 


\section{Background}

Postoperative nausea and vomiting (PONV) is one of the most common perioperative concerns, with a relatively high incidence of up to $73 \%$ after craniotomy [1-5]. PONV usually leads to patient discomfort, delayed discharge from the intensive care unit (ICU) or hospital, and increased medical costs [6]. Moreover, severe vomiting may result in dehydration, electrolyte imbalance, and acid-base disturbance [6].

Neurosurgical patients with PONV are at an increased risk of aspiration, intracranial or cerebral hypertension, hematoma formation, and neurological deterioration [7]. After craniotomy, PONV occurs with incidences up to $60 \%$ for emesis, and $70 \%$ for nausea when no prophylactic antiemetic is administered [8]. The etiology of PONV in patients undergoing craniotomy is probably multifactorial, and well-known risk factors of PONV include age, gender, a history of motion sickness, and previous PONV [9]. The effects of neurosurgical risk factors such as side and site of lesion, presence of midline shift and mass effect, and tumor pathology on PONV were evaluated, but no significant correlations were observed [3,10]. Fabling et al. [11] reported that PONV occurred frequently during the initial $48 \mathrm{~h}$ after craniotomy.

Various antiemetics, including anticholinergics and dopamine receptor antagonists, have been studied with regard to their efficacy for the prevention and treatment of PONV $[1,5,12]$. However, these agents have been reported to have adverse effects such as excessive sedation, hypotension, dysphoria, hallucinations, and extrapyramidal signs $[1,5,12,13]$, all of which are undesirable for neurological assessment after neurosurgical operations. Selective $5-\mathrm{HT}_{3}$ receptor antagonists (ondansetron, granisetron, and tropisetron) are effective in PONV after craniotomy without neurological adverse effects [1,3-5,7,11,14-17]. Ramosetron, a selective $5-\mathrm{HT}_{3}$ receptor antagonist, has been used effectively in various surgical procedures for the prevention or treatment of PONV [18]. However, limited data are available regarding the efficacy of ramosetron for the prevention of PONV in neurosurgical patients and it was suggested that prophylactic administration of ramosetron may reduce the incidence of PONV after craniotomy compared with ondansetron. This prospective, randomized, doubleblind, multi-center study was designed to evaluate the efficacy and safety profile of prophylactic administration of ramosetron for PONV in comparison with ondansetron after craniotomy.

\section{Methods}

\section{Patients}

The present study was performed at Seoul National University Hospital, Seoul National University Bundang Hospital, Severance Hospital, and Ewha Womans University Medical Center. The protocol was approved by the Ethics
Committees of each of the above hospitals and registered in the Clinical Research Information Service (CRiS, KCT0000320). After obtaining written and informed consent, 160 adult patients (American Society of Anesthesiologists [ASA] physical status I or II, aged 19-65 years) undergoing elective craniotomy from January 2012 until March 2013 were included.

Exclusion criteria were gastric disease, pregnancy, a history of craniotomy, anticancer chemotherapy, antiemetic use within $24 \mathrm{~h}$, severe renal (serum creatinine $>1.6 \mathrm{mg} / \mathrm{dl}$ ) or hepatic insufficiency (liver enzymes more than twice the normal value), borderline QTc prolongation ( $>430 \mathrm{msec}$ for males, $>450 \mathrm{msec}$ for females) on electrocardiography, chronic use of opioids for more than 2 weeks, antidepressant medication, having undergone an emergency operation, or those who could not understand the numerical rating scale (NRS) or communicate (scheduled to be sedated postoperatively).

\section{Anesthesia}

Anesthesia and monitoring were standardized for all patients. Patients received no preanesthetic medication. Standard monitoring included electrocardiography, pulse oximetry, and noninvasive blood pressure (NIBP) monitoring. Induction of anesthesia consisted of propofol $(4 \mu \mathrm{g} / \mathrm{ml})$ and remifentanil $(3-4 \mathrm{ng} / \mathrm{ml})$ using target controlled infusion (TCI). Neuromuscular blockade was performed using intravenous rocuronium $0.6 \mathrm{mg} / \mathrm{kg}$ to facilitate tracheal intubation. During anesthetic induction, a 20-gauge arterial catheter was inserted into a radial artery for continuous blood pressure (BP) monitoring or arterial blood sampling, and the subclavian vein was catheterized using a real-time ultrasound device to monitor central venous pressures. Propofol $(2-4 \mu \mathrm{g} / \mathrm{ml})$ and remifentanil (2-4 ng/ml) in oxygen and medical air $\left(\mathrm{FiO}_{2} 0.5\right)$ were used during maintenance of anesthesia. Ventilation was mechanically controlled to achieve end-tidal $\mathrm{CO}_{2}$ between 30 and $35 \mathrm{mmHg}$. Muscle relaxants were used as needed to maintain a single twitch on train-of-four stimulation. For intraoperative neurophysiological monitoring, no additional neuromuscular blocker was administered during surgery. Temperature was monitored using an esophageal stethoscope with thermistor and maintained at $36 \pm 1^{\circ} \mathrm{C}$ with a warm pad throughout surgery. At the end of the surgery, an intravenous patient-controlled analgesia (PCA) device was connected; the PCA consisted of fentanyl $15 \mu \mathrm{g} / \mathrm{ml}$ (total, $100 \mathrm{ml}$ ) and was programmed to run with a $1-\mathrm{ml}$ bolus dose and $10 \mathrm{~min}$ lockout time.

\section{Randomization and intervention}

Before induction of anesthesia, the anesthesiologist responsible for patient allocation randomized the patients using a computer-generated random number table (Random Allocation Software Version 1.0) with block size 3. 
Allocation was concealed with numbered sealed envelopes. Patients were allocated randomly to one of three groups to receive $4 \mathrm{mg}$ of ondansetron (group A), $8 \mathrm{mg}$ ondansetron (group B), or $0.3 \mathrm{mg}$ ramosetron (group $\mathrm{C}$ ) intravenously. Identical $5-\mathrm{ml}$ syringes containing the same volume (mixed with normal saline to the total volume of $4 \mathrm{ml}$ ) of ondansetron or ramosetron were prepared and administered at the end of surgery (dura mater closure) by blinded nurses to the group allocation.

\section{Outcomes}

After the operation, the patients were transferred to the intensive care unit (ICU). All patients were observed for $48 \mathrm{~h}$ postoperatively. Every episode of nausea or vomiting was recorded under three assessment time frames, 0-2 h, 2-24 h, and 24-48 h, by a blinded nurse. Nausea was defined as a subjectively unpleasant sensation associated with the awareness of the urge to vomit; retching was defined as labored, spasmodic, rhythmic contraction of the respiratory muscles without expulsion of gastric contents; vomiting was defined as the forceful expulsion of gastric contents from the mouth $[4,13]$. Complete response was regarded as no PONV. The severity of nausea (NRS with $0=$ none to $100=$ most severe) was evaluated verbally to guide the use of rescue antiemetics and, therefore, is not presented as a result. The rescue antiemetic used was 10-mg metoclopramide administered intravenously. This was given to patients whose NRS for nausea was greater than 30 and for patients who experienced more than one episode of vomiting or wanted to be treated.

Postoperative pain scores (using NRS with $0=$ none to $100=$ most severe) and consumption of PCA were also assessed. All adverse events were reviewed and judged by the investigator, and the details of clinically significant adverse events were supposed to be submitted to the Ethics Committees. Other postoperative adverse events, such as drowsiness, dizziness, and QTc prolongation, were also recorded.

\section{Statistical analysis}

In the previous study of Kathirvel et al., [3] the incidence of PONV $24 \mathrm{~h}$ postoperatively was $44 \%$ in patients with administration of ondansetron $4 \mathrm{mg}$ after craniotomy. A reduction of $30 \%$ in PONV with ramosetron was considered clinically significant. The analysis showed that 46 patients per group would be sufficient to detect the antiemetic effect of ramosetron $(\alpha=0.0175$ and $\beta=0.2$ ). We chose 55 patients per group assuming a $20 \%$ drop-out rate.

Continuous variables (age, height, weight, duration of surgery and anesthesia, pain score, and PCA consumption) were analyzed by ANOVA, and categorical variables (gender, ASA physical class, type of operation, preoperative dexamethasone, incidence of PONV and complete response, rescue analgesics, and adverse events) were compared using the chi-squared test or Fisher's exact test. Post hoc comparisons were made with Student Newman Keuls test. Data are expressed as means \pm standard deviation (SD) or counts (\%). A $p$ value less than 0.05 was deemed to indicate statistical significance.

\section{Results}

A total of 160 patients from four hospitals were enrolled in the present study, and 33 were excluded during allocation or the follow-up period. Ultimately, a total of 127 patients completed the study (Figure 1). Twenty-one patients were chosen to be sedated to protect their brains intra-operatively or postoperatively, and other patients were excluded due to perioperative massive bleeding $(n=3)$, lack of a postoperative patient visit $(n=2)$, minor protocol violations $(n=6$; errors in the PCA regimen and incorrect rescue antiemetics), and patient refusal (Figure 1). These violations did not impact subject safety and were considered minor. Patient characteristics and information on surgery and anesthesia are summarized in Table 1, and there were no statistically significant differences among the three groups with respect to patient demographic data.

The results for the 0 - to 48 - $\mathrm{h}$ study period suggested that the incidence of nausea $(\mathrm{P}<0.001)$ and the need for rescue antiemetics $(P=0.008)$ were lower in group $C$ than in groups A or B (Table 2). Additionally, the incidence of complete response $(\mathrm{P}<0.001)$ was significantly higher in group $\mathrm{C}$ than in groups $\mathrm{A}$ and $\mathrm{B}$ (Table 2). However, statistically significant differences in the incidence of PONV or complete response were not observed between A and B groups throughout the study period.

There were no significant differences in the incidence of PONV and the need for rescue antiemetics $0-2 \mathrm{~h}$ postoperatively. However, significant differences were observed in the incidence of PONV and complete response among the three groups $2-48 \mathrm{~h}$ postoperatively (Table 2). Nausea occurred less frequently and the rate of complete response was higher in group $\mathrm{C}$ than in group A or B 2-24 and 24-48 h postoperatively (Table 2). Additionally, rescue antiemetics were less frequently required in group $\mathrm{C}$ than in groups $\mathrm{A}$ or $\mathrm{B} 2-$ $48 \mathrm{~h}$ postoperatively (Table 2 ).

Total incidences of PONV for subgroups that did or did not receive dexamethasone were analyzed (Table 3). The incidence of nausea was lower and that of complete response was higher in group $\mathrm{C}$ than group $\mathrm{A}$ in both patients with or without steroid (Table 3).

No significant inter-group difference was observed in terms of postoperative pain or PCA consumption (Table 4). Common adverse events related to ramosetron treatment are headache, dizziness, and drowsiness. In the present study, headache was not checked because craniotomy 


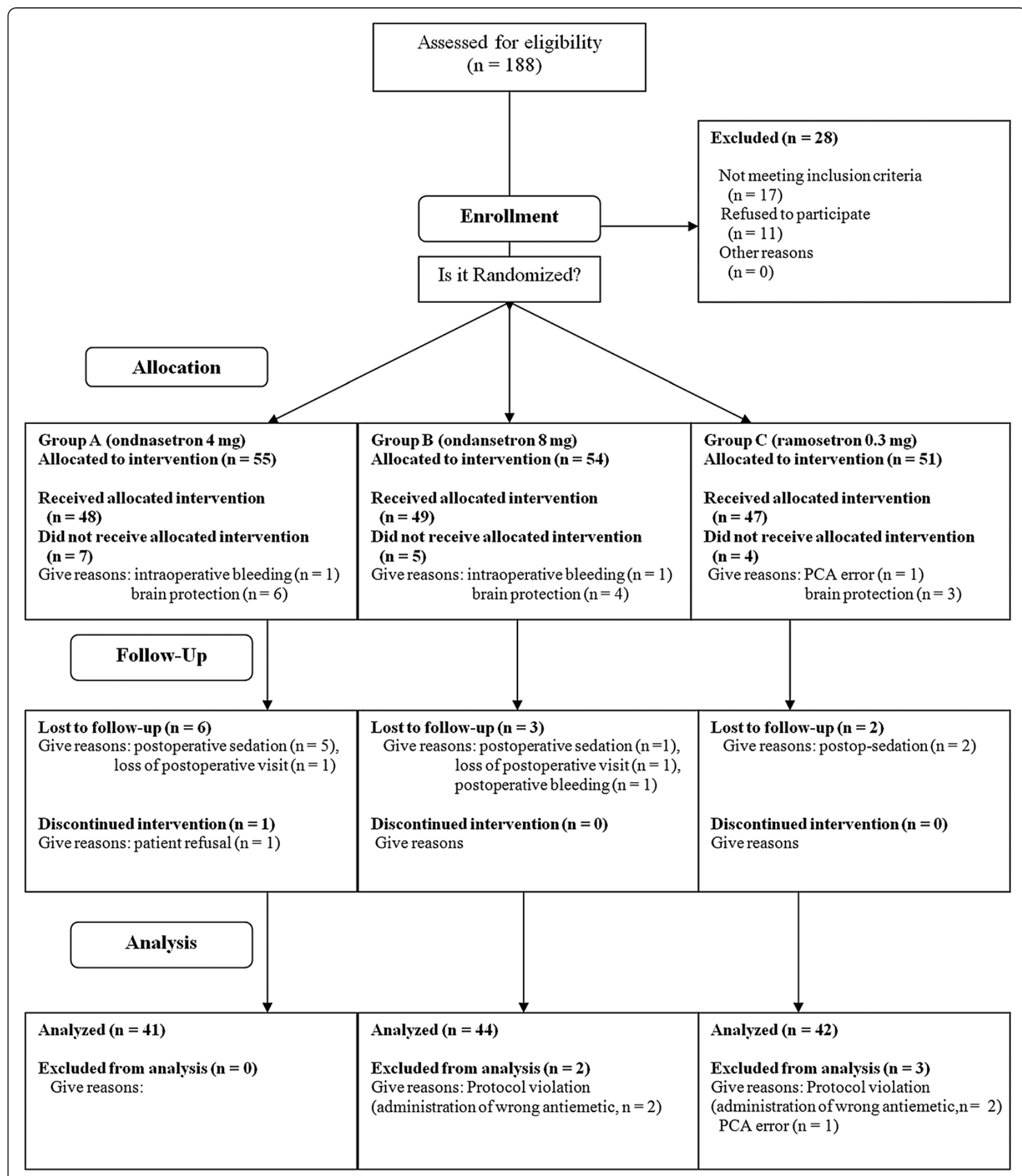

Figure 1 Flow diagram of the patients.

patients were enrolled. Rates of other adverse events, including drowsiness and dizziness, did not reach statistical significance among the groups (Table 4). There were no serious adverse events, such as QTc prolongation of electrocardiography or withdrawal of the study drugs.

\section{Discussion}

The present study was designed to evaluate the antiemetic efficacy of ramosetron in adult patients undergoing elective craniotomy. The overall incidence rates of PONV during the first $48 \mathrm{~h}$ after surgery were 63\%, 41\%, 
Table 1 Patients and surgery characteristics

\begin{tabular}{|c|c|c|c|c|}
\hline & Group A $(n=41)$ & Group B $(n=44)$ & Group C $(n=42)$ & $P$ value \\
\hline Age (yr) & $49(21-65)$ & $48(27-65)$ & $53(23-64)$ & 0.677 \\
\hline Weight (kg) & $62 \pm 11$ & $62 \pm 11$ & $63 \pm 11$ & 0.894 \\
\hline Height (cm) & $162 \pm 8$ & $163 \pm 8$ & $163 \pm 9$ & 0.728 \\
\hline Gender (M/F) & $14 / 27$ & $19 / 25$ & $13 / 29$ & 0.471 \\
\hline Preoperative dexamethasone & $17(41)$ & $15(34)$ & $11(26)$ & 0.339 \\
\hline Operation time (min) & $249 \pm 87$ & $288 \pm 117$ & $254 \pm 110$ & 0.179 \\
\hline Anesthesia time (min) & $321 \pm 90$ & $368 \pm 131$ & $327 \pm 114$ & 0.110 \\
\hline Type of surgery & & & & 0.322 \\
\hline Tumor surgery & $26(63)$ & $26(59)$ & $20(48)$ & \\
\hline Vascular surgery & $15(37)$ & $18(41)$ & $22(52)$ & \\
\hline ASA class I/II & $24(59) / 17(41)$ & $22(50) / 22(50)$ & $22(52) / 20(48)$ & 0.720 \\
\hline \multicolumn{5}{|l|}{ Preexisting disease, $(n)$} \\
\hline Hypertension & 11 & 13 & 13 & 0.916 \\
\hline Diabetes mellitus & 4 & 5 & 7 & 0.609 \\
\hline Liver disease & 3 & 2 & 0 & 0.223 \\
\hline
\end{tabular}

Group A; ondansetron $4 \mathrm{mg}$ group. Group B; ondansetron $8 \mathrm{mg}$ group. Group C; ramosetron $0.3 \mathrm{mg}$ group. Values are expressed as mean (SD) or number of the patients ( $\mathrm{n}$ ) except age (mean, range).

Table 2 Incidences of PONV and rescue antiemetics

\begin{tabular}{|c|c|c|c|c|}
\hline & Group A $(n=41)$ & Group B $(n=44)$ & Group C $(n=42)$ & $P$ value \\
\hline \multicolumn{5}{|l|}{ Postoperative 0-48 h } \\
\hline Nausea & $24(59)$ & $18(41)$ & $6(14)^{\dagger \neq}$ & $<0.001$ \\
\hline Retching \& Vomiting & $9(22)$ & $9(20)$ & $3(7)$ & 0.13 \\
\hline Complete response & $15(37)$ & $26(59)$ & $35(83)^{\dagger}$ & $<0.001$ \\
\hline Rescue antiemetic & $11(27)$ & $9(20)$ & $1(2)^{\dagger \neq}$ & 0.008 \\
\hline \multicolumn{5}{|l|}{ Postoperative $0-2 \mathrm{~h}$} \\
\hline Nausea & $6(15)$ & $5(11)$ & $2(5)$ & 0.318 \\
\hline Retching \& Vomiting & $1(2)$ & $1(2)$ & $1(5)$ & 0.999 \\
\hline Complete response & $34(83)$ & $40(91)$ & $40(95)$ & 0.172 \\
\hline Rescue antiemetic & $2(5)$ & $3(7)$ & $0(0)$ & 0.249 \\
\hline \multicolumn{5}{|l|}{ Postoperative 2-24 h } \\
\hline Nausea & $17(41)$ & $12(27)$ & $3(7)^{\dagger \neq}$ & 0.001 \\
\hline Retching \& Vomiting & $6(15)$ & $8(18)$ & $2(2)$ & 0.154 \\
\hline Complete response & $23(56)$ & $33(75)$ & $38(86)^{+}$ & 0.002 \\
\hline Rescue antiemetic & $8(20)$ & $5(11)$ & $1(2)^{\dagger}$ & 0.045 \\
\hline \multicolumn{5}{|l|}{ Postoperative $24-48$ h } \\
\hline Nausea & $16(39)$ & $14(32)$ & $4(10)^{\dagger}$ & 0.006 \\
\hline Retching \& Vomiting & $4(10)$ & $5(11)$ & $0(0)$ & 0.088 \\
\hline Complete response & $25(61)$ & $30(68)$ & $38(90)^{\dagger}$ & 0.006 \\
\hline Rescue antiemetic & $5(12)$ & $6(14)$ & $0(0)$ & 0.050 \\
\hline
\end{tabular}


Table 3 Incidences of PONV and rescue analgesic in patients with or without steroid

\begin{tabular}{|c|c|c|c|c|}
\hline Patients without steroid & Group A $(n=17)$ & Group B $(n=15)$ & Group C $(n=11)$ & $P$ value \\
\hline Nausea & $10(21)$ & $6(40)$ & $0(0)^{\dagger}$ & 0.007 \\
\hline Retching \& Vomiting & $3(17)$ & $1(7)$ & $0(0)$ & 0.265 \\
\hline Complete response & $7(41)$ & $9(60)$ & $11(100)^{\dagger}$ & 0.007 \\
\hline Rescue antiemetic & $4(24)$ & $2(13)$ & $0(0)$ & 0.214 \\
\hline Patients without steroid & Group A $(n=24)$ & Group B $(n=29)$ & Group $C(n=31)$ & $P$ value \\
\hline Nausea & $14(58)$ & $12(41)$ & $6(19)^{\dagger}$ & 0.012 \\
\hline Retching \& Vomiting & $6(25)$ & $8(27)$ & $3(10)$ & 0.178 \\
\hline Complete response & $9(37)$ & $17(58)$ & $24(77)^{\dagger}$ & 0.011 \\
\hline Rescue antiemetic & $7(29)$ & $7(24)$ & $1(3)^{\dagger}$ & 0.025 \\
\hline
\end{tabular}

Group A; ondansetron $4 \mathrm{mg}$ group. Group B; ondansetron $8 \mathrm{mg}$ group. Group C; ramosetron $0.3 \mathrm{mg}$ group.

Values are expressed as number of the patients (\%). $+:<0.0175$ compared with Group $A$.

and $17 \%$ in the ondansetron $4 \mathrm{mg}$, ondansetron $8 \mathrm{mg}$, and ramosetron $0.3 \mathrm{mg}$ groups, respectively. There was no placebo group in this study because high incidences of PONV after craniotomy were reported in previous investigations $[1,3,4]$. Administration of ramosetron $0.3 \mathrm{mg}$ at the time of dural closure significantly reduced the incidence of PONV and the requirement of rescue antiemetics compared with ondansetron $4 \mathrm{mg}$ or $8 \mathrm{mg} 48 \mathrm{~h}$ postoperatively without significant adverse events.

Ondansetron, one of the most common $5-\mathrm{HT}_{3}$ receptor antagonists, has been investigated for the prevention of PONV after craniotomy, and discrepant results have been reported regarding the effectiveness of ondansetron in neurosurgical patients $[1,11,14,15,17,19,20]$. Conversely, previous studies have indicated that the proper timing of ondansetron administration is at the time of dural closure for the prevention of PONV in neurosurgical patients [3,11,17]. Fabling et al. [11] recommended ondansetron $8 \mathrm{mg}$ for the prevention of PONV in highrisk neurosurgical patients. In the present study, the incidences of PONV after prevention with ondansetron 4 and $8 \mathrm{mg}$ were 63 and $41 \%$, respectively.

Ramosetron, another selective $5-\mathrm{HT}_{3}$ receptor antagonist, has been reported to be effective for the prevention and treatment of PONV after various surgeries [21-27]. Previous investigations have shown that ramosetron $0.3 \mathrm{mg}$ was more effective than ondansetron $4 \mathrm{mg}$ in patients with spine surgery, total knee arthroplasty, and laparoscopic cholecystectomy $[22,24,27]$ and as effective as ondansetron $8 \mathrm{mg}$ in patients with gynecological surgery and laparoscopic surgery [25,27]. However, no data have been reported concerning the antiemetic efficacy of ramosetron for preventing PONV after craniotomy. It is noteworthy that ramosetron $0.3 \mathrm{mg}$ was more effective than ondansetron $8 \mathrm{mg}$ after craniotomy in the present study. This may have been because the incidence and

Table 4 Postoperative pain, recovery profiles and postoperative adverse effects

\begin{tabular}{|c|c|c|c|c|}
\hline & Group A $(n=41)$ & Group B $(n=44)$ & Group C $(n=42)$ & $P$ value \\
\hline \multicolumn{5}{|l|}{ Postoperative $0-2 \mathrm{~h}$} \\
\hline Pain (VRS) & $36(0-80)$ & $41(0-90)$ & $39(0-100)$ & 0.974 \\
\hline PCA consumption (ml) & $1.5(0-7)$ & $1.5(0-8)$ & $1.5(0-5)$ & 0.921 \\
\hline \multicolumn{5}{|l|}{ Postoperative 2-24 h } \\
\hline Pain (VRS) & $27(0-100)$ & $26(0-85)$ & $26(0-70)$ & 0.792 \\
\hline PCA consumption (ml) & $11(0-46)$ & $12(20-75)$ & $13(0-78)$ & 0.541 \\
\hline \multicolumn{5}{|l|}{ Postoperative 24-48 h } \\
\hline Pain (VRS) & $17(0-80)$ & $15(0-60)$ & 18(0-70) & 0.589 \\
\hline PCA consumption (ml) & $16(1-95)$ & $26(0.2-100)$ & $22(0-88)$ & 0.345 \\
\hline \multicolumn{5}{|l|}{ Advervse events } \\
\hline Drowsiness & $4(10)$ & $5(11)$ & $2(5)$ & 0.528 \\
\hline Dizziness & $7(17)$ & $14(32)$ & $6(14)$ & 0.101 \\
\hline Itching & $1(2)$ & $1(2)$ & $0(0)$ & 0.604 \\
\hline Others & $1(2)$ & $0(0)$ & $0(0)$ & 0.347 \\
\hline
\end{tabular}

Group $\mathrm{A}$; ondansetron $4 \mathrm{mg}$ group. Group B; ondansetron $8 \mathrm{mg}$ group. Group C; ramosetron $0.3 \mathrm{mg}$ group. Values are expressed as median (range) or number of the patients (\%). 
degree of PONV after craniotomy are higher than those in other surgeries.

Several factors should be taken into consideration during investigations of PONV in patients with craniotomy. PONV in neurosurgical patients is affected by postcraniotomy pain and PCA consumption [4]. In the current study, there were no statistically significant differences in postcraniotomy pain and PCA consumption among the groups, and these factors may be considered to have minimal effect on the results. Additionally, instead of inhalation agents, total intravenous anesthesia with propofol and remifentanil was used for maintenance of anesthesia to monitor the evoked potential and reduce PONV. The most frequent adverse event following administration of the selective $5-\mathrm{HT}_{3}$ receptor antagonist is headache. Headache was not recorded because it is difficult to discriminate headache from postcraniotomy pain in patients with neurosurgery.

These phenomena could be explained by the potency of the two drugs. The results of previous meta-analyses showed that ramosetron was effective for preventing PONV without adverse effects and also had statistically significant differences for prevention of early and late PONV compared with ondansetron [18,28]. However, ramosetron (about US $\$ 23$ for $0.3 \mathrm{mg}$ ) is more expensive than ondansetron (US $\$ 5$ for $4 \mathrm{mg}$ and US $\$ 8$ for $8 \mathrm{mg}$ ) in Korea. The choice and use of antiemetics should be individualized considering cost effective benefits.

The present study had a few limitations. First, the study population consisted of patients with various intracranial diseases, including tumors and vascular lesions. Additionally, patients with intracranial tumors may be using preoperative dexamethasone to reduce cerebral edema. Dexamethasone, a corticosteroid, has effective antiemetic action and reduces the degree and incidence of PONV [29], although few studies have investigated the effects of preoperative steroid use on the incidence of PONV in neurosurgical patients. In the present study, no significant differences were found in the number of patients with preoperative steroid use among the three groups, a finding that may cause some (but minimal) confusion in the interpretation of the results. Second, the incidences of PONV in patients with craniotomy were reported to be high, and combined antiemetic measures with different sites of action are recommended for this high-risk group [9]. The aim of the present study was to evaluate the efficacy of ramosetron alone for the prevention of PONV in neurosurgical patients, and further studies of combination antiemetics for neurosurgical patients are needed. Third, the sample size calculation was based on the previous investigation of Kathirvel et al. and the incidence of PONV was 44\% [3]. However, all patients of Kathirvel's investigation received dexamethasone for 24 hours whereas $34 \%$ of the patients in this study were administered preoperative dexamethasone. In addition, anesthesia was maintained with $\mathrm{N} 2 \mathrm{O}$ and isoflurane in the previous study of Kathirvel et al. [3] instead of TIVA using propofol-remifentanil of the present study. These factors may have influenced on the incidence of PONV. Forth, minimal calculated sample size estimated to detect the difference in the primary outcome among the three study groups (46 patients per group) was not finally achieved because more patients than we expected have been dropped out during study period of the 4 centers. This may influence the statistical significance in that the lack of difference between the two ondansetron groups could be related to inadequate sample size.

\section{Conclusion}

Intravenous administration of ramosetron $0.3 \mathrm{mg}$ at the end of surgery was more effective than ondansetron 4 or $8 \mathrm{mg}$ for the prevention of PONV in patients undergoing elective craniotomy under total intravenous anesthesia using propofol and remifentanil. Future studies of multimodal prophylactic strategies with ramosetron and other antiemetics in this high-risk patient population are needed.

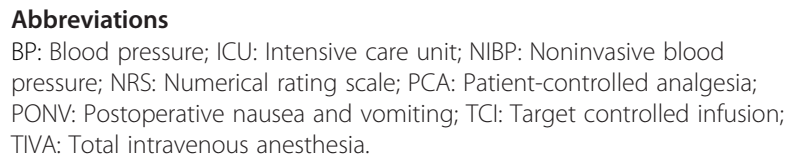

\section{Competing interests}

The authors have no conflicts of interest or financial ties to disclose.

\section{Authors' contributions}

$J H R, Y J L, H J P, K T M$ and SHD contributed study design. JEL, DMH, HPP, JH, and $\mathrm{HZK}$ collected and analyzed data. JHR and SHD drafted the manuscript. $J H R, H J B$ and KTM made critical revisions of the manuscript. All authors read and approved the final analysis of the manuscript.

\section{Acknowledgements}

The authors thank MRCC (medical research cooperation center) of Seoul National University Bundang Hospital for their statistical assistance.

\section{Author details}

${ }^{1}$ Department of Anesthesiology and Pain Medicine, Seoul National University Bundang Hospital, 166 Gumi-ro, Bundang-gu, Seongnam-si, Gyeonggi-do 463-707, South Korea. ${ }^{2}$ Department of Anesthesiology and Pain Medicine, Seoul National University Hospital, Seoul, South Korea. ${ }^{3}$ Department of Anesthesiology and Pain Medicine, College of Medicine, Seoul National University, Seoul, South Korea. ${ }^{4}$ Department of Anesthesiology and Pain Medicine, School of Medicine, Ewha Womans University, Seoul, Korea. ${ }^{5}$ Department of Anesthesiology and Pain Medicine, Severance Hospital, Seoul, South Korea.

Received: 21 March 2014 Accepted: 28 July 2014

Published: 4 August 2014

\section{References}

1. Fabling JM, Gan TJ, El-Moalem HE, Warner DS, Borel CO: A randomized, double-blinded comparison of ondansetron, droperidol, and placebo for prevention of postoperative nausea and vomiting after supratentorial craniotomy. Anesth Analg 2000, 91(2):358-361. 
2. Fabling JM, Gan TJ, Guy J, Borel CO, El-Moalem HE, Warner DS: Postoperative nausea and vomiting. A retrospective analysis in patients undergoing elective craniotomy. J Neurosurg Anesthesiol 1997, 9(4):308-312.

3. Kathirvel S, Dash HH, Bhatia A, Subramaniam B, Prakash A, Shenoy S: Effect of prophylactic ondansetron on postoperative nausea and vomiting after elective craniotomy. J Neurosurg Anesthesiol 2001, 13(3):207-212.

4. Madenoglu H, Yildiz K, Dogru K, Kurtsoy A, Guler G, Boyaci A: Randomized, double-blinded comparison of tropisetron and placebo for prevention of postoperative nausea and vomiting after supratentorial craniotomy. J Neurosurg Anesthesiol 2003, 15(2):82-86.

5. Pugh SC, Jones NC, Barsoum LZ: A comparison of prophylactic ondansetron and metoclopramide administration in patients undergoing major neurosurgical procedures. Anaesthesia 1996, 51(12):1162-1164.

6. Kovac AL: Prevention and treatment of postoperative nausea and vomiting. Drugs 2000, 59(2):213-243.

7. Neufeld SM, Newburn-Cook CV: The efficacy of 5-HT3 receptor antagonists for the prevention of postoperative nausea and vomiting after craniotomy: a meta-analysis. J Neurosurg Anesthesio/ 2007, 19(1):10-17.

8. Eberhart LH, Morin AM, Kranke P, Missaghi NB, Durieux ME, Himmelseher S: Prevention and control of postoperative nausea and vomiting in postcraniotomy patients. Best Pract Res Clin Anaesthesiol 2007, 21(4):575-593.

9. Gan TJ, Meyer T, Apfel CC, Chung F, Davis PJ, Eubanks S, Kovac A, Philip BK, Sessler DI, Temo J, Gan TJ, Meyer T, Apfel CC, Chung F, Davis PJ, Eubanks S, Kovac A, Philip BK, Sessler DI, Temo J, Tramèr MR, Watcha M: Consensus guidelines for managing postoperative nausea and vomiting. Anesth Analg 2003, 97(1):62-71. Table of contents.

10. Irefin SA, Schubert A, Bloomfield EL, DeBoer GE, Mascha EJ, Ebrahim ZY: The effect of craniotomy location on postoperative pain and nausea. J Anesth 2003, 17(4):227-231.

11. Fabling JM, Gan TJ, El-Moalem HE, Warner DS, Borel CO: A randomized, double-blind comparison of ondansetron versus placebo for prevention of nausea and vomiting after infratentorial craniotomy. J Neurosurg Anesthesiol 2002, 14(2):102-107.

12. Meng L, Quinlan JJ: Assessing risk factors for postoperative nausea and vomiting: a retrospective study in patients undergoing retromastoid craniectomy with microvascular decompression of cranial nerves. J Neurosurg Anesthesiol 2006, 18(4):235-239.

13. Watcha MF, White PF: Postoperative nausea and vomiting. Its etiology, treatment, and prevention. Anesthesiology 1992, 77(1):162-184.

14. Hartsell T, Long D, Kirsch JR: The efficacy of postoperative ondansetron (Zofran) orally disintegrating tablets for preventing nausea and vomiting after acoustic neuroma surgery. Anesth Analg 2005, 101(5):1492-1496.

15. Jain V, Mitra JK, Rath GP, Prabhakar H, Bithal PK, Dash HH: A randomized, double-blinded comparison of ondansetron, granisetron, and placebo for prevention of postoperative nausea and vomiting after supratentorial craniotomy. J Neurosurg Anesthesiol 2009, 21(3):226-230.

16. Wang YJ, Cheng ZG, Guo QL: Clinical observation of granisetron in preventing postoperative nausea and vomiting following supratentorial craniotomy. Hunan Yi Ke Da Xue Xue Bao 2002, 27(6):545-546.

17. Wig J, Chandrashekharappa KN, Yaddanapudi LN, Nakra D, Mukherjee KK: Effect of prophylactic ondansetron on postoperative nausea and vomiting in patients on preoperative steroids undergoing craniotomy for supratentorial tumors. J Neurosurg Anesthesiol 2007, 19(4):239-242.

18. Kim WO, Koo BN, Kim YK, Kil HK: Ramosetron for the prevention of postoperative nausea and vomiting (PONV): a meta-analysis. Korean J Anesthesiol 2011, 61(5):405-412.

19. Habib AS, Keifer JC, Borel CO, White WD, Gan TJ: A comparison of the combination of aprepitant and dexamethasone versus the combination of ondansetron and dexamethasone for the prevention of postoperative nausea and vomiting in patients undergoing craniotomy. Anesth Analg 2011, 112(4):813-818.

20. Sinha PK, Tripathi M, Ambesh SP: Efficacy of ondansetron in prophylaxis of postoperative nausea and vomiting in patients following infratentorial surgery: a placebo-controlled prospective double-blind study. J Neurosurg Anesthesiol 1999, 11(1):6-10.

21. Choi DK, Chin JH, Lee EH, Lim OB, Chung CH, Ro YJ, Choi IC: Prophylactic control of post-operative nausea and vomiting using ondansetron and ramosetron after cardiac surgery. Acta Anaesthesiol Scand 2010, 54(8):962-969.

22. Choi YS, Shim JK, Ahn SH, Kwak YL: Efficacy comparison of ramosetron with ondansetron on preventing nausea and vomiting in high-risk patients following spine surgery with a single bolus of dexamethasone as an adjunct. Korean J Anesthesiol 2012, 62(6):543-547.

23. Choi YS, Shim JK, Yoon Do H, Jeon DH, Lee JY, Kwak YL: Effect of ramosetron on patient-controlled analgesia related nausea and vomiting after spine surgery in highly susceptible patients: comparison with ondansetron. Spine (Phila Pa 1976) 2008, 33(17):E602-E606.

24. Hahm TS, Ko JS, Choi SJ, Gwak MS: Comparison of the prophylactic antiemetic efficacy of ramosetron and ondansetron in patients at high-risk for postoperative nausea and vomiting after total knee replacement. Anaesthesia 2010, 65(5):500-504.

25. Kim SI, Kim SC, Baek YH, Ok SY, Kim SH: Comparison of ramosetron with ondansetron for prevention of postoperative nausea and vomiting in patients undergoing gynaecological surgery. Br J Anaesth 2009, 103(4):549-553.

26. Lee JW, Park HJ, Choi J, Park SJ, Kang H, Kim EG: Comparison of ramosetron's and ondansetron's preventive anti-emetic effects in highly susceptible patients undergoing abdominal hysterectomy. Korean J Anesthesiol 2011, 61(6):488-492.

27. Ryu J, So YM, Hwang J, Do SH: Ramosetron versus ondansetron for the prevention of postoperative nausea and vomiting after laparoscopic cholecystectomy. Surg Endosc 2010, 24(4):812-817.

28. Mihara T, Tojo K, Uchimoto K, Morita S, Goto T: Reevaluation of the effectiveness of ramosetron for preventing postoperative nausea and vomiting: a systematic review and meta-analysis. Anesth Analg 2013, 117(2):329-339.

29. De Oliveira GS Jr, Castro-Alves L, Ahmad S, Kendall MC, McCarthy RJ: Dexamethasone to prevent postoperative nausea and vomiting: an updated meta-analysis of randomized controlled trials. Anesth Analg 2013, 116(1):58-74.

doi:10.1186/1471-2253-14-63

Cite this article as: Ryu et al:: A prospective, randomized, double-blind, and multicenter trial of prophylactic effects of ramosetron on postoperative nausea and vomiting (PONV) after craniotomy: comparison with ondansetron. BMC Anesthesiology 2014 14:63.

\section{Submit your next manuscript to BioMed Central and take full advantage of:}

- Convenient online submission

- Thorough peer review

- No space constraints or color figure charges

- Immediate publication on acceptance

- Inclusion in PubMed, CAS, Scopus and Google Scholar

- Research which is freely available for redistribution 